\title{
Primer cutan anaplasiás CD30+ nagysejtes lymphoma kóresete
}

\section{A case of primary cutaneous CD30+ anaplastic large cell lymphoma}

\author{
RÓZSA ANNAMÁRIA DR. ${ }^{1}$, MOJZES JENŐ DR. ${ }^{2}$, KÁLMÁN ENDRE DR. ${ }^{3}$, \\ SZOMOR ÁRPÁD DR. ${ }^{4}$, KOVÁCS L. ANDRÁS DR. ${ }^{1}$, VÁRSZEGI DALMA DR. ${ }^{1}$, \\ BATTYÁNI ZITA DR. ${ }^{1}$
}

Pécsi Tudományegyetem Klinikai Központ, Bőr-, Nemikórtani és

Onkodermatológiai Klinika, Pécs ${ }^{1}$,

Dombóvári Szent Lukács Egészségügyi Nonprofit Kft.,

Bőr- és Nemibeteg Gondozó Intézet, Dombóvár²,

Pécsi Tudományegyetem Klinikai Központ, Pathológiai Intézet, Pécs ${ }^{3}$

Pécsi Tudományegyetem Klinikai Központ, I. sz. Belgyógyászati Klinika, Pécs ${ }^{4}$

\section{ÖSSZEFOGLALÁS}

A szerzók egy 20 éves fiatal férfibeteg esetét ismertetik, akinél a jobb nasolabiális redóben lévő ulcerált tumor szövettani vizsgálata primer cutan CD30+ anaplasiás nagysejtes lymphomát igazolt, melynek kivizsgálása során szisztematizáció nem mutatkozott. A börfolyamat kb. 3 hónap alatt spontán, teljes mértékben regrediált. A beteget szoros kontroll alatt tartják, recidívát eddig nem észleltek. A kóresettel a szerzók felhívják a figyelmet arra, hogy a fenti tumor esetén javasolt obszerváció, mivel várható a daganat spontán visszafejlödése, emiatt mérlegelendö a korai agresszív terápia halasztása.

\section{Kulcsszavak: \\ primer cutan anaplasiás CD30+ nagysejtes lymphoma - spontán regresszió - agresszív terápia halasztása}

\section{SUMMARY}

The authors present the case of a 20-year-old male patient with an ulcerated tumour in the right nasolabial fold. The histopathological examination confirmed primary cutaneous CD 30+ anaplastic large cell lymphoma. During work-up no lymph node, blood or internal organ involvement was detected. The neoplasm showed complete spontaneous regression in about 3 months. The patient is under frequent follow-up, recurrence has not yet been detected. The case history underlines that in the case of the above mentioned tumours close observation is recommended since spontaneous regression is expected, postponement of early aggressive therapy should be considered.

\section{Key words: \\ primary cutaneous CD30+ anaplastic large cell lymphoma - spontaneous regression - postponement of aggressive therapy}

A primer cutan lymphomák lehetnek T- vagy B-sejt eredetűek. A diagnózis felállításának idôpontjában az extracutan manifesztáció kizárható $(1,2)$. A T-sejtes lymphomák kb. 65\%-ot tesznek ki (1). A primer cutan CD30+ lymphoproliferatív betegségek egyik képviselóje a primer cutan anaplasiás nagysejtes lymphoma (PCALCL). A PCALCL incidenciájának csúcsa 60 év körülire tehetô, de fiatal felnőtteket, gyermekeket is érinthet a megbetegedés. A PCALCL prognózisa jó, jellemző a szisztémás érintettség hiánya, indolens lefolyás, spontán remisszió, terápia utáni alacsony kiújulási ráta, valamint disszemináció ritka előfordulása (3).

\section{Esetismertetés}

A 20 éves férfibeteget a területileg illetékes bőrgyógyászati szakrendelésen 2011 májusában a jobb nasolabiális redó mellett elhelyezkedő hyperaemiás alapon csoportos vesiculákkal, jobb oldali submandibuláris megnagyobbodott nyirokcsomóval észlelték. Anamnézisében komolyabb belbetegség nem szerepel, családi anamnézise malignitás irányában negatív. Láza nem jelentkezett, külföldön nem tartózkodott, fogászati beavatkozás nem történt. Herpes simplex gyanúja miatt alkalmazott szisztémás antivirális terápia ellenére a beteg bőrfolyamata progrediált, típusos furunculusnak megfelelő bőrtüneteket észleltek, a beteg fül-orr-gégészeti osztályos felvétele történt.

Az elvégzett vizsgálatok során a bakterológiai leoltás negatívnak bizonyult és a laboratóriumi eredményekben kórosat nem találtak. Tekintettel a fokozódó infiltrációra szisztémás antibiotikum terápia

Levelező szerző: Dr. Rózsa Annamária, Pécsi KK, Bőr-, Nemikórtani és Bőronkológiai Klinika, Pécs e-mail:rozsa.annamaria@pte.hu 


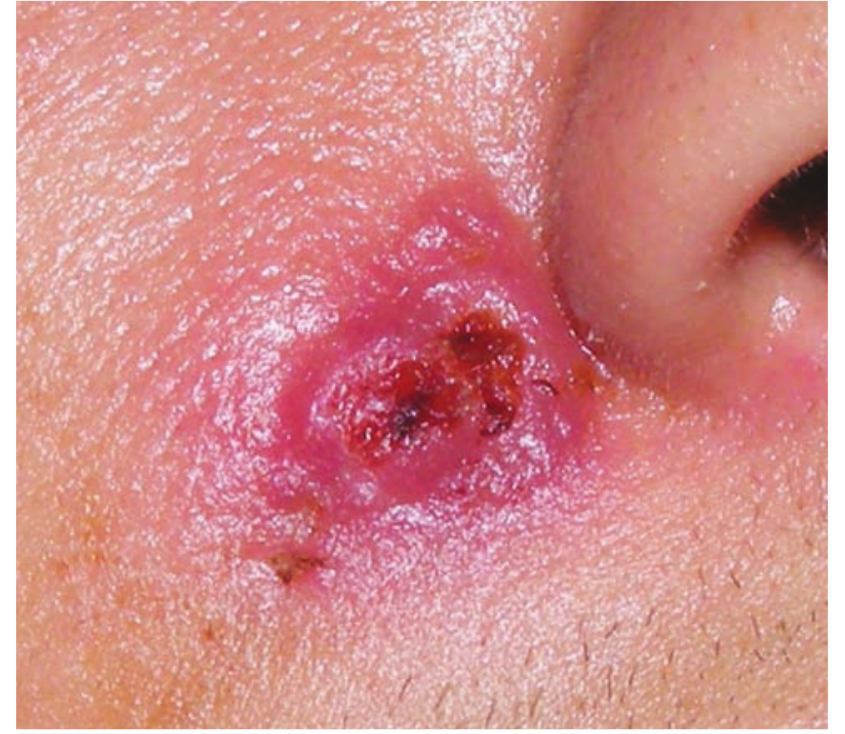

1. ábra

A jobb oldali nasolabiális redőben 1,5 cm átmérôjű, hyperaemiás, tömött tapintatú, ulcerált tumor

(amoxicillin/klavulánsav) indult, amely mellett javulás nem jelentkezett. Fogászati vizsgálat gócot nem igazolt

A beteg 3 hete fennálló bőrfolyamattal, a jobb orrszárny mellett elhelyezkedő $1,5 \mathrm{~cm}$ átmérőjú hyperaemiás, tömött tapintatú, centrálisan ulcerált tumorral került osztályos felvételre klinikánkra (1. ábra).

Differenciáldiagnosztikai szempontból felmerült granuloma faciale, chancriform pyoderma, aktinomycosis, leishmaniasis és cutan lymphoma lehetősége is.

Laboratóriumi vizsgálatok (máj-, vesefunkció, vércukor, vérkép, CRP) normál tartományban voltak. A képalkotó vizsgálatok közül mellkas röntgen vizsgálattal kórosat nem találtunk, hasi ultrahang vizsgálat organomegaliát, megnagyobbodott hasi nyirokcsomót nem mutatott ki. Nyaki ultrahang vizsgálat mko. parajugulárisan több kisebb, jobb oldalt submandibulárisan 1 nagyobb reaktív nyirokcsomót írt le.

A nem gyógyuló, heges, infiltrált tumorból szövettani vizsgálat céljából próbaexcíziót végeztünk. Haematoxylin-eosin festéssel a dermisben sejtdús, diffúz, lymphoid sejtes infiltrátum mutatkozott epidermotropizmus nélkül. Az infiltrátumot középnagy méretú, kissé egyenetlen, behúzott magvú, mitotikusan aktív sejtek alkották (2. ábra). Az immunhisztokémiai vizsgálattal a CD3 és CD4 pozitív sejtek kiterjedt CD30 pozitivitást mutattak TIA-1 expresszió mellett (3. ábra). A B-sejtekre jellemző MUM-1 expresszió negatív volt. A

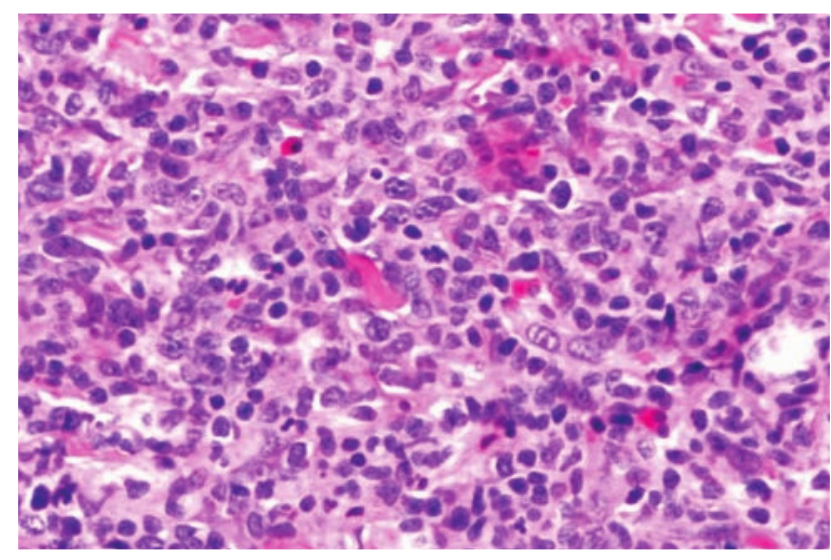

2. ábra

A dermisben közepes, néhol behúzott magvú, mitotikusan aktív lymphocyták (HE, 40x)

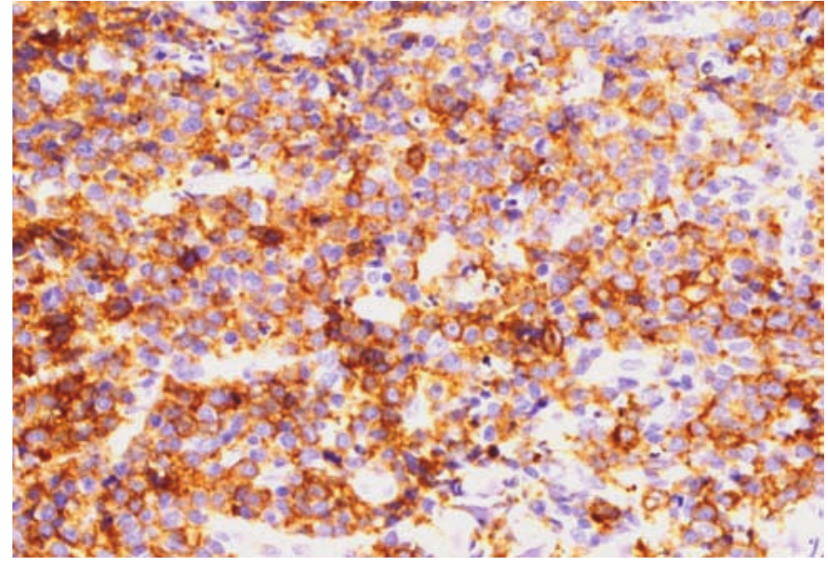

3. ábra

CD30+ tumorsejtek (IH. CD30, 20x)

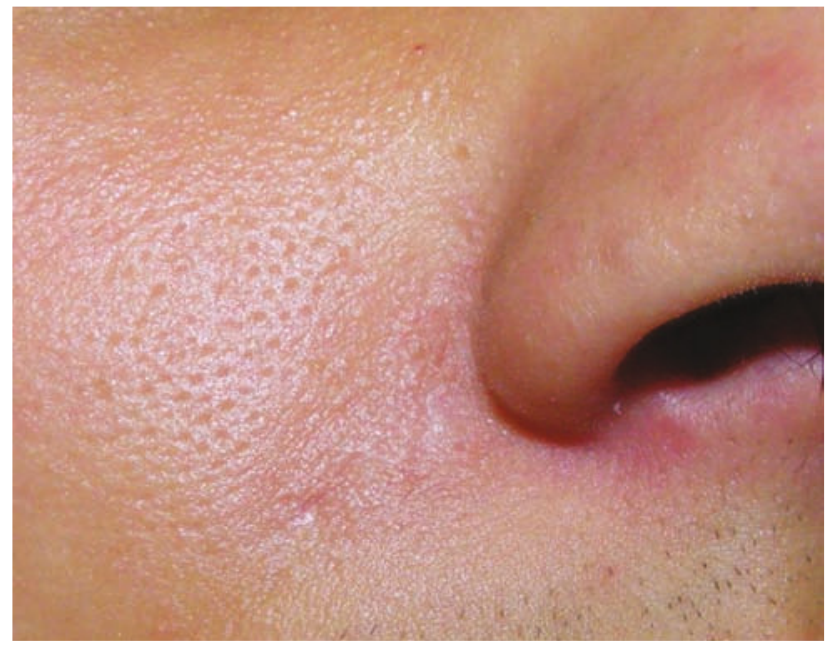

4. ábra

Tünetmentes állapot spontán remisszió után

bốr excindátumból izolált DNS-en elvégzett PCR vizsgálat klonális T-sejt receptor (TCR) gamma génátrendeződést igazolt. A perifériás vér áramlási citometriai vizsgálata fiziológiás $\mathrm{CD} 4 / \mathrm{CD} 8$ arányt mutatott. A csontvelőben normocelluláris, kiérő haemopoesis volt látható.

Staging vizsgálatok (koponya-, mellkas-, has-, kismedencei CT) a bőrfolyamat szisztematizációját kizárták.

A klinikai kép, bőr biopsziás minta szövettani és immunhisztokémiai vizsgálata, valamint a negatív staging eredmények alapján primer cutan anaplasiás nagy T-sejtes lymphoma diagnózist állítottunk fel, melyet T1aN0M0 stádiumba soroltunk. Az onkoteam döntése alapján radioterápiát javasoltunk, azonban ezt a beteg nem vállalta, mivel bőrfolyamata spontán (lokálisan kizárólag antiszeptikus externákat alkalmaztunk) kb. 3 hónap alatt teljes mértékben regrediált (4. ábra). A beteget szorosan kontrolláljuk, recidíva nem jelentkezett.

\section{Megbeszélés}

A primer cutan lymphomák a non-Hodgkin lymphomák közé tartoznak. Primer folyamatról akkor beszélünk, ha a diagnózis felállításának időpontjában kizárólag bőrérintettség igazolható, az extracutan manifesztáció kizárható. Secunder cutan lymphoma abban az esetben áll fenn, ha a bőrtünetek mellet nyirokcsomó- vagy egyéb belszervi érintettség is kimutatható. A cutan lymphomák kb. kétharmada T-sejt eredetú, a B-sejtes folyamatok ritkábbak. 


\section{A cutan lymphomák WHO besorolása (2008)}

\section{Cutan T- és NK-sejtes lymphomák}

Mycosis fungoides

Sézary-szindróma

Felnőttkori T-sejtes leukaemia/lymphoma

Primer cutan CD30+ T-sejtes lymphoproliferatív betegségek:

- Primer cutan anaplasiás nagysejtes lymphoma

- Lymphomatoid papulosis

Subcutan panniculitis-like T-sejtes lymphoma

Extranodális NK/T-sejtes lymphoma, nasalis típus

Primer cutan perifériás T-sejtes lymphoma, ritka altípusok

- Primer cutan CD8+ agresszív epidermotrop cytotoxikus lymphoma (provisionalis entitás)

- Primer cutan $\gamma / \delta$ T-sejtes lymphoma

- Primer cutan CD4+ kis/közepes T-sejtes lymphoma (provisionalis entitás)

\section{Cutan B-sejtes lymphomák}

Extranodalis marginális zóna lymphoma

Primer cutan follicularis centrum lymphoma

Diffúz nagy B-sejtes lymphoma, NOS

Primer cutan diffúz nagy B-sejtes lymphoma, lábszári típus

Intravascularis nagy B-sejtes lymphoma

\section{Prekurzor haematológiai neoplasma}

Blastos plasmocytoid dentritikus sejtes neoplasma

\section{1. táblázat}

Cutan lymphomák WHO klasszifikációja (17) antikonvulzívumok), fertőző ágensek (EBV, HHV-8, HTLV-I, Borrelia burgdorferi, Helicobacter pylori, Chlamydia psittaci) (19). A PCALC etiológiája és patogenezise napjainkban sem tisztázott. Hellier és munkatársai EBV infekció és PCALC közti összefüggést vizsgálták, EBV kimutatására 3 különböző metódust alkalmazva (PCR, in situ hibridizáció, immunhisztokémiai vizsgálatok) lymphomás ill. tünetmentes bőrmintából. Mindhárom módszerrel csupán 1 lymphomás bőrtünetből mutattak ki EBV DNS-t, mindegyik mintában a tünetmentes bốr vírusmentes volt (20).

A PCALCL egy CD4+ T-sejtes tumor, amelyet szabálytalan magvú, világos citoplazmájú nagy anaplasticus sejtek alkotnak. A daganat a subcutan szövetig terjedhet, gyakran perivascularis infiltráció figyelhető meg. A tumorinfiltrátum széli részén kis, reaktív lymphocytagyülem lehet, akut gyulladásos sejtek jelenléte ulceratív léziónál jellemző. Ismertek az ún. neutrophilben gazdag ,pyogen” és eosinophilben gazdag ritka ALCL szövettani variánsok is (13). A PCALCL kb. 20$30 \%$-ában pseudoepitheliomatosus hyperplasia figyelhetô meg, amely kezdetben laphámsejtes carcinomával té-

Felosztásuk jelenleg a 2008-as WHO szerinti klasszifikáció alapján történik (1. táblázat).

A PCALCL a mycosis fungoides (MF) után a második leggyakrabban előforduló bőrlymphoma, a cutan lymphomák kb. 9\%-a. Idősebb betegeknél, átlagban 60 év körül jelentkezik, férfiaknál gyakoribb (férfi:nő = 2-3:1) (4). Gyermekeknél ritka, fiatal felnőttkori manifesztáció esetén az anamnézisben gyermekkori atopiás ekcéma szerepelhet (9). A diagnózis felállításához a következő kritériumoknak kell teljesülni: (a) a bőr biopsziás minta $>75 \%$ ban $\mathrm{CD} 30+$ nagysejtes anaplasiás sejtinfiltrációt mutat, (b) anamnézisben lymphomatoid papulosis (Lyp), MF vagy egyéb cutan lymphoma ne forduljon elő, (c) a diagnózis felállításának időpontjában extracutan manifesztáció kizárható (5). A betegséget szoliter vagy csoportosan megjelenő, gyorsan növekvő nodusok vagy plakkok jellemzik, melyek ulcerálódhatnak és főként a végtagokon, ill. a fej-nyak régióban helyezkednek el. Ismert multiplex vagy disszeminált formája is, amelyek előfordulása viszont ritka (6). Extracutan érintettség az esetek kb. 10\%ban jelentkezik, általában regionális lymphadenopathiával, de csontvelő beszúrtség, központi idegrendszeri és gastrointestinális infiltráció is jelen lehet.

A lymphoproliferatív betegségek etiológiájában több tényező kóroki szerepét valószínúsítik: növényvédőszerek, rovarirtók, textilgyártásban, festék- és fémiparban használt vegyi anyagok, gyógyszerek (immunszuppresszív szerek, veszthető össze (14). A tumorsejtek erős CD30 membrán és Golgi zóna pozitivitást mutatnak, citotoxikus proteinek (TIA-1, granzyme B, perforin) expressziójával. EMA pozitivitás 20-30\%-ban előfordulhat, de mint az EMA, mint az ALK pozitivitás szisztémás ALCL-re jellemző (15).

A betegséget el kell különíteni a szekunder bőrérintettséggel járó szisztémás nodális ALCL-től, ill. egyéb szekunder formáktól, amelyek Lyp, MF transzformálódása révén alakulnak ki $(6,16)$. Differenciáldiagnosztikailag felmerülhet még felnőttkori ekcéma, pyoderma gangrenosum, morphea és laphámsejtes carcinoma (21).

A betegség stádium besorolásához staging vizsgálatokat kell végezni. Kivizsgálás során a rutin laboratóriumi vizsgálatokon kívül (vérkép, vörösvértestsüllyedés, máj-, vesefunkció, vizelet általános és üledék vizsgálat, CRP, béta-2 mikroglobulin szint) perifériás vér flow citometriás vizsgálat, képalkotó vizsgálatok (mellkasi, hasi- és kismedencei CT), megnagyobbodott nyirokcsomó excíziója és citogenetikai analízis szükségesek, vérképeltérésnél csontvelővizsgálatot kell végezni (19). Jelenleg a PCALCL stádiumának meghatározása a nem MF és Sézaryszindróma típusú primer cutan lymphomák TNM beosztása alapján történik (6).

A betegség prognózisa kedvező, az 5 éves túlélés 95\%ra tehető (1). A PCALCL-es léziók $25 \%$-a visszafejlődik (7). A magas remissziós ráta miatt javasolt a betegek 4-6 hétig történő megfigyelése. Amennyiben a tumor spontán 
regressziója következik be, nem szükséges további terápia, a beteg szoros kontrollja javasolt. Csak a betegek kis számában nem várható további kiújulás, ezért a spontán regrediáló eseteknél elsődleges az obszerváció a betegség követésében (22). Legtöbb PCALCL esetnél nincs spontán regresszió, a terápiás döntést a léziók száma (szoliter v. multiplex) határozza meg.

A PCALCL kemo- és sugárérzékeny lymphoma. Szoliter tumorok esetén a sebészi excízió javasolt törekedve a tumormentes ép szegélyre. Sugárkezelésként elektronbesugárzás alkalmazható (4-10 millió eV) 40 Gy összdózissal (7). Mivel az elektronsugarak a dermis mélységéig hatolnak, szisztémás mellékhatásokkal nem kell számolni, lokálisan alopecia, verejtékmirigy atrófia, ödéma, radiodermatitis alakulhat ki. Nem regrediáló multiplex formáknál szisztémás kezelés választandó. Alacsony dózisú methotrexat (heti $10-25 \mathrm{mg}$ ) általában hatásos a daganat remissziójában $(8,10)$. Refrakter vagy methotrexat mellett progrediáló eseteknél orális etoposid lehet sikeres (11). Egyéb terápiás lehetôségként purin nukleozid analóg (pentostatin), retinoidok, interferon- $\alpha$, interleukin-12, imiquimod, bexaroten alkalmazható (7). Anti-CD30 monoklonális antitest terápiával végzett vizsgálatok jó eredményeket mutatnak, mint a cutan, mint a szisztémás ALCL-ben (12). Extracutan disszemináció esetén CHOP (ciklofoszfamid, doxorubicin, vincristin, prednisolon) kemoterápia bevezetése szükséges, magas rizikójú betegeknél őssejt transzplantáció mérlegelendő (7).

$\mathrm{Az}$ általunk bemutatott kóresetben fiatal korban jelentkező, spontán regressziót mutató PCALCL igazolódott. $\mathrm{Az}$ anamnézisben gyermekkori atopiás dermatitis nem szerepel. 2 éves követés után betegünk jelenleg tünet- és panaszmentes.

Esetünkkel az arcra lokalizálódó ritkán előforduló, indolens lefolyású daganat differenciáldiagnosztikai és terápiás jelentőségére hívjuk fel a figyelmet, kiemelve a folyamat szoros obszervációjának fontosságát, és amennyiben lehetséges a korai agresszív terápia halasztását.

\section{IRODALOM}

1. Willemze R., Jaffe E. S., Burg G. és mtsai.: WHO-EORTC classification for cutaneous lymphomas. Blood. (2005) 105, 3768-3785.

2. Kim Y. H., Willemze R., Pimpinelli N. és mtsai.: TNM classification system for primary cutaneous lymphomas other than mycosis fungoides and Sezary syndrome: a proposal of the International Society For Cutaneous Lymphomas (ISCL) and the Cutaneous Lymphoma Task Force of The European Organization of Research and Treatment of Cancer (EORTC) Blood. (2007) 110, 479-484.

3. Tomaszewski M. M., Moad J. C., Lupton G. P.: Primary cutaneous Ki-1 (CD30) positive anaplastic large cell lymphoma in childhood. J Am Acad Dermatol. (1999) 40, 857-861.

4. Bekkenk M. W., Geelen F. A., van Voorst Vader P. C. és mtsai.. Primary and secondary cutaneous CD30+ lymphoproliferative disorders; a report from the Dutch Cutaneous Group on the long term follow-up data of 219 patients and guidelines for diagnosis and treatment. Blood. (2000) 95, 3653.
5. Török L., Krenács L., Kirschner Á. és mtsai.: Primer cutan CD30-pozitív nagysejtes anaplasiás lymphoma spontán regresszióval. Bőrgyógy. Vener. Szle. (2005) 81, 147-149.

6. Erös N., Marschalkó M., Holló P. és mtsai.: Kiterjedt bőrérintettséggel járó primer cutan anaplasiás nagy sejtes lymphoma sikeres kezelés röntgen irradiációval. Bőrgyógy. Vener. Szle. (2010) 86, 116-119.

7. Marshall E. Kadin, Francine Foss: Primary Cutaneous and Systemic CD30+ T-cell Lymphoproliferative Disorders. T-Cell Lymphomas, Contemporary Hematology. (2013) 71-86.

8. Vonderheid E. C., Sajjadian A., Kadin M. E.: Methotrexate is effective therapy for lymphomatoid papulosis and other primary cutaneous CD30-positive lymphoproliferative disorders. J Am Acad Dermatol. (1996) 34, 470-81.

9. Fletcher C. L., Orchard G. E., Hubbard V. és mtsai.: CD30(+) cutaneous lymphoma in association with atopic eczema. Arch Dermatol. (2004) 140(4), 449-454.

10. Kadin M. E.: Current management of primary cutaneous CD30+ T-cell lymphoproliferative disorders. Oncology (Williston Park). (2009) 23(13), 1158-1164.

11. Yamane N., Kato N., Nishimura M. és mtsai.: Primary cutaneous CD30+ anaplastic large-cell lymphoma with generalized skin involvement and involvement of one peripheral lymph node, successfully treated with low-dose oral etoposide. Clin Exp Dermatol. (2009) 34(5), 56-59.

12. Duvic M., Reddy S. A., Pinter-Brown L. és mtsai.: A phase II study of SGN-30 in cutaneous anaplastic large cell lymphoma and related lymphoproliferative disorders. Clin Cancer Res. (2009) 15(19), 6217-6224.

13. Kong Y. Y., Dai B., Kong J. C. és mtsai.: Neutrophil/eosinophilrich type of primary cutaneous anaplastic large cell lymphoma: a clinicopathological, immunophenotypic and molecular study of nine cases. Histopathology. (2009) 55(2), 189-196.

14. Zayour M., Gilmore E., Heald P. és mtsai.: A distinct entity in the spectrum of the $\mathrm{CD} 30+$ cutaneous lymphoproliferative diseases: oligolesional nodules with pseudoepitheliomatous hyperplasia followed by spontaneous resolution. Am J Dermatopathol. (2009) 31(1), 37-43.

15. Vergier B., Beylot-Barry M., Pulford K. és mtsai.: Statistical evaluation of diagnostic and prognostic features of CD30+ cutaneous lymphoproliferative disorders: a clinicopathologic study of 65 cases. Am J Surg Pathol. (1998) 22(10), $1192-1202$.

16. Kárpáti S., Kemény L. és Remenyik É.: Bőrgyógyászat és Venerológia. 1. kiadás, Budapest: Medicina; (2013) 827 p.

17. Kárpáti S., Kemény L. és Remenyik É.: Bőrgyógyászat és Venerológia. 1. kiadás, Budapest: Medicina; (2013) 818 p.

18. ESMO Guidelines Working Group, Dummer R: Primary cutaneous lymphomas. ESMO clinical recommendations for diagnosis, treatment and follow-up. Ann Oncol. (2007) 18(2), 61-62.

19. Erös N.: Cutan lymphomák klinikopatológiai jellegzetességeinek vizsgálata, Egyetemi doktori (Phd) értekezés, Semmelweis Egyetem Általános Orvostudományi Kar Bőr-, Nemikórtani és Bốronkológiai Klinika, Budapest; (2009) 5-6 p.

20. Hellier I., Dereure O., Segondy M. és mtsai.: Unlikely role of Epstein-Barr virus in the pathogenesis of primary cutaneous CD30+ anaplastic large cell lymphoma. Eu J. Dermatol. (2001) 11(3), 203-208.

21. Camisa C., Helm N. T., Sexton C. és mtsai.: Ki-1 positive anaplastic large cell lymphoma can mimic benign dermatoses. J Am Acad Dermatol. (1993) 29, 696-700.

22. Willemze R., Beljaards R. C.: Spectrum of primary cutaneous CD30 (Ki-1)-positive lymphoproliferative disorders. A proposal for classification and guidelines for management and treatment. J Am Acad Dermatol. (1993) 28, 973-80.

Érkezett: 2013. 06. 14.

Közlésre elfogadva: 2013. 07. 19. 